\title{
MICROBIOLOGICAL QUALITY ASSESSMENT FOR OYSTERS PRODUCED AND TRADED IN PARANÁ, BRAZIL
}

\author{
M.T.M. MontanhinI* and R. Montanhini Neto \\ Veterinary Sciences, Federal University of Paraná, 80035-050 Curitiba. Brazil
}

(Received: 02 January 2014; accepted: 10 March 2014)

\begin{abstract}
Oysters are filter-feeding bivalve molluscs that are associated with several foodborne illnesses, because they accumulate biotic and abiotic contaminants dispersed in the water. The state of Paraná in southern Brazil is distinguished by a high consumption of oysters, typically eaten raw, and this habit may present a risk to consumer health if the product is contaminated with pathogenic bacteria. This study intends to evaluate the microbiological quality of oysters produced and traded in Paraná, directly examining the localities of cultivation and trading of the product. The major sites for the trading of oysters in the state were identified and 52 dozen oysters (624 animals) were collected from these places, between April and December, 2013. The samples were subjected to analyses for total coliforms, Escherichia coli, Staphylococcus aureus, and Salmonella spp. No samples had results of microbial contamination above the limits established by Brazilian legislation. This study indicated that the microbiological quality of the oysters produced and traded in the state of Paraná is acceptable.
\end{abstract}

Keywords: bivalve molluscs, coliforms, contamination, pathogenic, public health

Oyster consumption has increased considerably throughout the globe over the past two decades; thus, oysters have become the second most commercially important marine organism for aquaculture worldwide (FAO, 2012). On the other hand, according to POTASMAN and coworkers (2002), the infectious outbreaks associated with bivalve shellfish consumption have increased proportionally; most cases have been reported in the United States, Australia, and other European and Asian countries. Brazil stands out in production and consumption of this shellfish. On the coast of the state of Paraná, a producer harvesting oysters from the Crassostrea genus (Sacco, 1897) generates income for fishermen and their families. Further, this company increasingly promotes gastronomic tourism (CHAves et al., 2002). However, producing such oysters is an artisanal practice, and the producers and handlers lack information about the appropriate processing and storage conditions to ensure microbiological quality and guarantee consumer safety (ANDRIGUETTo-FilHo et al., 2009).

Bivalves collect their feed (suspended plankton, detritus, and organic matter) by filtering water without a selection mechanism and ingesting particles only limited by size (DunPHy et al., 2006). Where pathogenic microorganisms or toxin producer microalgae are in the water, they may be retained and concentrated in the shellfish's organism (SILVA et al., 2004). If processing and preparation is not efficient at removing (through depuration) or destroying (through cooking) these microorganisms or toxins, oyster consumption may be dangerous to public health (ROBERTSON, 2007). Still, among all microorganisms that might contaminate raw oysters, the Brazilian regulation has only limits concerning to Escherichia coli,

* To whom correspondence should be addressed.

Phone: +33 44331 14 13; fax: +33 4700980 05; e-mail: maikemaziero@yahoo.com.br

0139-3006/\$20.00 @ 2015 Akadémiai Kiadó, Budapest 
Staphylococcus aureus, and Salmonella spp., as well as some microalgae's toxins (BRAzIL, 2001, 2012a).

Because it is necessary to establish a monitoring program for quality of oysters that are produced and traded in Paraná, the objective was to evaluate microbiological quality for such oysters at cultivation and trading, in accordance with the Brazilian legal requirements.

\section{Materials and methods}

To trace a diagnosis of oysters produced in Paraná trading, the ten most populous cities in the state were selected from the Brazilian Institute of Geography and Statistics database (IBGE, 2012). From this information, fishmongers and fish and seafood markets available in each of these cities were identified (EDITEL, 2013). Each of these trade localities was sent a questionnaire regarding the marketing of oysters, their presentation (fresh or frozen), and origin. From the data obtained, those cities were selected for subsequent collecting of samples for microbiological evaluation, where the consumption of oysters is typical.

Fifty-two dozen Crassostrea sp. of fresh oysters (624 animals) were evaluated between April and December, 2013. The oysters were obtained directly at the cultivation localities in

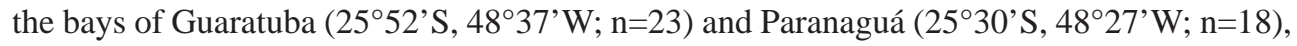
and the fishmongers and markets were located in the metropolitan region of Curitiba (main city of Paraná; $\mathrm{n}=11$ ). Each collected dozen represented a sample at microbiological analysis.

The samples were transported in accordance with recommendations by the Codex Alimentarius Commission (CAC, 1999, 2008), and less than 18 hours elapsed between the sample collection and initial analysis steps. The microbiological analyses were performed in the microbiology laboratory, Department of Agricultural Sciences, Federal University of Paraná. Each sample included a dozen oysters. In the laboratory, the oysters' shells were washed using sterile brushes under running water and opened using sterilized knives. The inner material of the animal, comprised the intervalvular liquid and meat, was fully collected (Silva et al., 2010). The samples were homogenized in a stomacher and diluted in saline peptone water.

Microbiological analyses were performed, wherein the total coliforms and E. coli on Petrifilm EC as well as S. aureus on Petrifilm STX Staph Express Count Plates were counted (SILVA et al., 2010). The presence of Salmonella spp. was evaluated in $25 \mathrm{~g}$ of each oyster sample. For this analysis, a pre-enrichment was performed followed by selective enrichment in selenite cystine broth (SC) and Rappaport Vassiliadis (RV) broth. After, the samples were inoculated onto Salmonella-Shigella agar (SS) and Xylose Lysine Deoxycholate agar (XLD). Suspected colonies were subjected to biochemical tests using Lysine iron agar (LIA), triple sugar iron agar (TSI), and serum serology with polyvalent anti-Salmonella "O" (BRAZIL, 2003). Contamination levels of $E$. coli were compared with IN 07 (BRAzIL, 2012a), and of $S$. aureus and Samollena spp. with RDC 12 (BRAZIL, 2001).

The results for the analysed samples were tabulated and grouped by oysters' origin (Paranaguá Bay, Guaratuba Bay or Santa Catarina), collection locality (cultivations or markets), and season at collection. The microbiological data were log transformed, which aided comparisons of the data. Each group was compared and evaluated for interactions between groups using the non-parametric Kruskal-Wallis test with the software Statistica (Statsoft Inc.). 


\section{Results and discussion}

In the metropolitan region of Curitiba (municipalities of Colombo, Curitiba, and São José dos Pinhais) and the state's coast (municipality of Paranaguá), among the 34 points of marketing, 13 (38\%) had oysters available, and in eight fishmongers the oysters were produced in Paraná. This fact can be explained by the shorter distance from the cultivation sites (within $100 \mathrm{~km}$ ), which reduces the transport time associated with the habit of consumption of seafood by the population of these regions (Table 1). On the other hand, among the 44 fishmongers located in the countryside region (municipalities of Cascavel, Foz do Iguassu, Guarapuava, Londrina, Maringá, and Ponta Grossa), only nine (20.5\%) offered oysters for sale, and in eight of these they came from Santa Catarina. The reason of this low availability of the product to the trade, according to information obtained by the questionnaire, was the short shelf-life due to the high rate of deterioration. Combined with this factor, the demand for the product is also low in this region. The fishmongers offered oysters presented in raw or frozen forms. Frozen oysters were sold as flesh meat without shells, bundled in sealed plastic bags for further cooking proposes, and stored at temperatures between -10 and $-20^{\circ} \mathrm{C}$; however, raw oysters were sold alive in shells, intended for raw or cooked consumption, and stored at room temperature (between 15 and $25^{\circ} \mathrm{C}$ ) or under mild refrigeration (between 5 and $15^{\circ} \mathrm{C}$ ).

Table 1. Information obtained from questionnaire about oyster trading by fishmongers present in the ten most populous cities of Paraná, Brazil (n=78).

\begin{tabular}{lcccc}
\hline Municipality & Listed fishmongers ${ }^{1}$ & $\begin{array}{c}\text { Fishmongers selling } \\
\text { oysters }\end{array}$ & $\begin{array}{c}\text { Oysters presentation } \\
\text { Origin of the } \\
\text { oysters }\end{array}$ \\
\hline Curitiba & 25 & 10 & Raw and/or Frozen ${ }^{2}$ & SC $^{*}(5)$ and PR PR $^{* *}(5)$ \\
Londrina & 13 & 1 & Raw & SC \\
Maringá & 10 & 2 & Frozen & SC and PR \\
Ponta Grossa & 4 & 0 & - & - \\
Cascavel & 4 & 1 & Frozen & SC \\
São José dos & 4 & Frozen & SC \\
Pinhais & 11 & 1 & Frozen & SC \\
Foz do Iguassu & 1 & 3 & Frozen & PR \\
Colombo & 2 & 1 & Frozen & SC \\
Guarapuava & 4 & 2 & Frozen & PR \\
Paranaguá & & 2 & & \\
\hline
\end{tabular}

${ }^{1}$ : EDITEL (2013); ${ }^{2}$ : Frozen oysters were sold as flesh meat without shells, bundled in sealed plastic bags for further cooking purposes, and stored at temperatures between -10 and $-20{ }^{\circ} \mathrm{C}$; however, raw oysters were sold alive in shells, intended for raw or cooked consumption, and stored at room temperature (between 15 and $25^{\circ} \mathrm{C}$ ) or under mild refrigeration (between 5 and $15^{\circ} \mathrm{C}$ ). ${ }^{*}$ : SC - Coast of Santa Catarina. ${ }^{* *}$ : PR - Coast of Paraná.

Since the trading of oysters produced in Paraná takes place primarily on the coast and in the metropolitan region of Curitiba, the sampling was restricted to these regions. The Crassostrea sp. oyster samples evaluated herein yielded results consistent with the current Brazilian standards for S. aureus, E. coli, and Salmonella spp., which is indicative of the microbiological acceptable quality for oysters produced and traded in Paraná (Table 2). 
Table 2. Results for the total coliforms, Escherichia coli, and Staphylococcus aureus after analysing raw Crassostrea oyster samples produced and traded in Paraná, Brazil, between April and December 2013 (n=52).

\begin{tabular}{|c|c|c|c|}
\hline & Total coliforms & E. coli & S. aureus \\
\hline \multicolumn{4}{|l|}{ Microbiological results } \\
\hline Samples below the detection limit $\left(<10 \mathrm{CFU} \mathrm{g}^{-1}\right.$ ) & 15 (28.85\%) & $42(80.77 \%)$ & 46 (88.46\%) \\
\hline Global mean count $\left(\log _{10} \mathrm{CFU} \mathrm{g}^{-1}\right)$ & $1.253( \pm 0.906)$ & $0.222( \pm 0.463)$ & $0.210( \pm 0.617)$ \\
\hline Mean count above the detection limit $\left(\log _{10} \mathrm{CFU} \mathrm{g}{ }^{-1}\right)$ & $1.761( \pm 0.494)$ & $1.154( \pm 0.145)$ & $1.830( \pm 0.613)$ \\
\hline Maximum count $\left(\log _{10} \mathrm{CFU} \mathrm{g}^{-1}\right)$ & 2.654 & 1.322 & 2.700 \\
\hline Samples disagreement with Brazilian standards ${ }^{1}$ & $-x^{-2}$ & 0 & 0 \\
\hline \multicolumn{4}{|c|}{ Mean count above the detection limit (in $\log _{10} \mathrm{CFU} \mathrm{g}^{-1}$ ) in each evaluated collection locality } \\
\hline Cultivations $(n=25)$ & $1.887( \pm 0.412)$ & $1.162( \pm 0.150)$ & $1.041( \pm 0.410)^{\mathrm{b}}$ \\
\hline Markets (n=27) & $1.635( \pm 0.541)$ & $1.146( \pm 0.162)$ & $2.619( \pm 0.533)^{\mathrm{a}}$ \\
\hline \multicolumn{4}{|c|}{ Mean count above the detection limit (in $\log _{10} \mathrm{CFU} \mathrm{g}^{-1}$ ) in each evaluated harvesting area } \\
\hline Guaratuba Bay $(n=23)$ & $1.773( \pm 0.540)$ & $1.181( \pm 0.154)$ & $1.552( \pm 0.454)^{b}$ \\
\hline Paranaguá Bay (n=18) & $1.845( \pm 0.460)$ & $1.183( \pm 0.199)$ & $1.322( \pm 0.467)^{\mathrm{b}}$ \\
\hline Coast of Santa Catarina (n=11) & $1.665( \pm 0.385)$ & $1.098( \pm 0.204)$ & $2.616( \pm 0.280)^{\mathrm{a}}$ \\
\hline \multicolumn{4}{|c|}{ Mean count above the detection limit (in $\log _{10} C F U g^{-1}$ ) in each evaluated season } \\
\hline Autumn $(n=12)$ & $2.041( \pm 0.674)^{\mathrm{a}}$ & $1.251( \pm 0.198)^{\mathrm{a}}$ & $1.740( \pm 0.412)$ \\
\hline Winter $(n=16)$ & $0.866( \pm 0.535)^{\mathrm{b}}$ & $0.387( \pm 0.132)^{\mathrm{b}}$ & $2.225( \pm 0.417)$ \\
\hline Spring $(\mathrm{n}=18)$ & $1.829( \pm 0.489)^{\mathrm{a}}$ & $0.903( \pm 0.176)^{\mathrm{a}}$ & $1.774( \pm 0.471)$ \\
\hline Summer $(n=6)$ & $2.308( \pm 0.702)^{\mathrm{a}}$ & $2.075( \pm 0.256)^{\mathrm{a}}$ & $1.581( \pm 0.523)$ \\
\hline
\end{tabular}

1: Standards for E. coli defined by BrazIL (2012a) and S. aureus by BRAzIL (2001). ${ }^{2}$ : No regulatory standard in Brazil. ${ }^{\text {a,b }}$ : Distinct letters in the same column differ significantly for the nonparametric Kruskal-Wallis test.

For the samples tested, $28.85 \%$, 80.77\%, and $88.46 \%$ were contaminated at levels below the limits of detection for the methods used to detect the total coliforms, E. coli, and $S$. aureus, respectively. Of the total samples tested, 28.9\% yielded results below the limits for the three microbiological tests. The general count means were also low: $1.253 \mathrm{CFU} \mathrm{g}^{-1}$ for the total coliforms, $0.222 \mathrm{CFU} \mathrm{g}^{-1}$ for E. coli; and $0.210 \mathrm{CFU} \mathrm{g}^{-1}$ for S. aureus.

The total coliforms analysis showed the highest mean score. The total coliforms is a subgroup of the Enterobacteriaceae family with more than 20 species, including bacteria from human and other animals intestine, as well as non-enteric bacteria. Although such microorganisms are considered indicators for hygiene conditions in food handling, Brazilian legislation limits the total coliforms in raw oysters (SILVA et al., 2010). Escherichia coli indicate faecal contamination which may result from domestic effluents in the cultivation area (Dufour, 1977). Ingesting E. coli can cause several types of intestinal infection, which symptoms may include: acute, watery, profuse, or severe diarrhoea, abdominal pain, vomiting, fever, nausea, dehydration, bloody stools, headache, and myalgia. Such infections can last from 6 hours to 14 days (KoHLER \& Dobrindt, 2011).

No samples showed contamination by Salmonella spp. The same result was reported by PEREIRA and co-workers (2006) who evaluated oysters from Santa Catarina. This microorganism is the main etiological agent responsible for outbreaks in Paraná; however, 
none of them were associated with consumption of oysters or even fisheries (Kotrwitz et al., 2010). Nevertheless, the U.S. Food and Drug Administration found an overall Salmonella incidence of 7.42\% in seafood, between 1990 and 1998 (HeInItz et al., 2000). BRANDS and co-workers (2005) reported that $7.4 \%$ of oysters from the coast of the United Stated were contaminated by Salmonella. On the other hand, AsAi and co-workers (2008) found a low prevalence (0.57\%) of Salmonella spp. in 353 samples of 29 types of seafood in Japan. Several salmonellosis outbreaks associated with seafood products have recently been reported by international surveillance agencies; however, the real incidence of these illnesses is probably underestimated (AmAGLIANI et al., 2012).

All samples were also within the expected contamination level for $S$. aureus and the global mean count found for this analysis was the lowest among the microorganisms evaluated in this study. Contamination by $S$. aureus mainly comes from the handling process, which may explain the low levels, since the raw oysters are not handled, and are generally consumed from the shell (BENNETT et al., 2013). However, regarding the collection locality, it was observed that the oysters from the markets showed levels of contamination by S. aureus significantly higher than those obtained in cultivated environments.

Moreover, oysters produced from coast of Santa Catarina had significantly higher contamination levels of this bacterium than those from coast of Paraná. This can be explained by the fact that, to reach the commercialization locality, oysters suffer more manipulation during transport (between 200 and $300 \mathrm{~km}$ ) and storage in addition to the longer period out of the water. In this study, $65.2 \%$ of the markets sell oysters from Santa Catarina, located further south, currently the largest producer of oysters in Brazil (BRAzIL, 2012b). Besides, some of interviewed fishmongers limit themselves to sell products from suppliers who are registered by the Federal Inspection Service, most available in Santa Catarina. PEREIRA and co-workers (2006) evaluated 90 oyster dozens traded in Santa Catarina and observed E. coli in four samples (9\%) collected from cultivations and 16 samples (35.5\%) collected from restaurants. In the same study, oyster contamination by Salmonella spp., S. aureus, Vibrio cholerae, and V. parahaemolyticus were also evaluated, and each sample showed acceptable contamination levels.

Greater contamination by total coliforms and E. coli was detected in the warm and moderate seasons (summer, spring, and autumn) and in winter, the contamination levels for such microorganisms were significantly lower (Table 2); no differences were observed for $S$. aureus contamination among seasons. Climatic conditions influence the water temperature and salinity as well as promotes changes in coliform contamination levels in seawater and, consequently, marine products (CHIGBU et al., 2004). In addition to such factors, the water for this region includes less organic matter in the winter, which may also influence the bacterial biomass in the water and, consequently, oysters (Montanhini Neto et al., 2013). Another factor for consideration is the increased fluctuating population on the coast of Paraná during the warm seasons, especially summer, which promotes an increase in domestic effluent volume discharged into the environment (CHAvEs et al., 2002). Altogether, these factors may explain the lower bacterial growth during the winter compared with the other seasons.

Despite the oysters evaluated in this study being in agreement with the legal standards in Brazil, the main etiological agents involved in outbreaks related to consumption of oysters are the hepatitis A virus and calicivirus, followed by bacteria from the Vibrio and Salmonella genus (PotASMAn et al., 2002). Shellfish may also convey protozoal diseases, particularly Cryptosporidium spp., Giardia duodenalis, and Toxoplasma gondii (RoBerTson, 2007). In addition to these agents, oysters can accumulate marine biotoxins produced by some species 
of microscopic algae and may cause various types of intoxications, including: paralytic shellfish poisoning (PSP); amnesic shellfish poisoning (ASP); neurotoxins shellfish poisoning (NSP); and diarrheal shellfish poisoning (DSP), among other toxins (Ciminiello \& FATTORusso, 2006).

The rate of oyster deterioration after a harvest is influenced by the initial microorganism quantity and type. During the transport and storage stages, adverse conditions (low oxygen levels, waste accumulation and food interruption) promote changes in the microbiota. In addition to such factors, storage temperature strongly influences diversity for this microbiota (FERNANDEZ-Piquer et al., 2012). One factor for consideration is that, although oysters remain alive for a certain period after harvesting, they must be consumed while their shells are closed (an indication that they are alive) because the risk of contamination is much lower. After death, deterioration and microorganism development are more rapid because oysters have high protein values, high moisture levels, and a tissue $\mathrm{pH}$ near 7 , which facilitates enzyme and microorganism activities. Thus, oysters are one of the foods most susceptible to deterioration (LAIRD, 1961).

Considering the oyster production chain in Paraná's coastal region, it was observed that the producers limit their production to trading at the cultivation sites, where customers come to buy oysters for residential consumption. This trade is significantly higher in summer, when the flow of tourists in the coastal area is intense. In this case, oysters are harvested daily and made available to consumers at room temperature, and live oysters not sold are returned to sea water.

\section{Conclusions}

Oysters produced and traded in Paraná showed satisfactory microbiological quality and were in agreement with the standards established by Brazilian legislation. Nevertheless, production of the state is still small and is restricted to local and informal trade and it is essential to continuously monitor the quality of raw oysters in the state from production to the final consumer.

The authors thank the Araucaria Foundation for Research Support of the State of Paraná (Fundação Araucária) and the Brazilian Coordination for Higher Education Staff Development (CAPES) for granting post-doctorate funding to Dr Maike T.M. Montanhini.

\section{References}

Amagliani, G., Brandi, G. \& Schiavano, G.F. (2012): Incidence and role of Salmonella in seafood safety. Food Res. Int., 45, 780-788.

Andriguetto-Filho, J.M., Krul, R. \& Feitosa, S. (2009): Analysis of natural and social dynamics of fishery production systems in Paraná, Brazil: implications for management and sustainability. J. Appl. Ichthyol., 25, 277-286.

Asai, Y., Kaneko, M., Ohtsuka, K., Morita, Y., Kaneko, S., Noda, H., Furukawa, I., Takatori, K. \& Hara-Kudo, Y. (2008): Salmonella prevalence in seafood imported into Japan. J. Food Prot., 71, 1460-1464.

Bennett, R.W., Hait, J.M. \& Tallent, S.M. (2013): Staphylococcus aureus. -in: Labbé, R.G. \& García, S. (Eds) Guide to foodborne pathogens. John Wiley \& Sons, West Sussex, pp. 26-44.

Brands, D.A., Inman, A.E., Gerba, C.P., Maré, C.J., Billington, S.J., SAif, L.A., Levine, J.F. \& Joens, L.A. (2005): Prevalence of Salmonella spp. in oysters in the United States. Appl. Environ. Microbiol., 71, 893-897.

Brazil (2001): Regulamento técnico sobre padrões microbiológicos para alimentos (Technical regulation on microbiological standards for foods). Resolution of the College Board No. 12, from January 2nd, 2001, Brasília: Ministry of Health, National Health Surveillance Agency. 
Brazil (2003): Métodos analíticos oficiais para análises microbiológicas para controle de produtos de origem animal e água (Official analytical methods for microbiological analysis for control of animal products and water). Normative Instruction No. 62, August 26th, 2003, Brasília: Ministry of Agriculture, Livestock, and Food Supply.

Brazil (2012a): Programa nacional de controle higienico-sanitário de moluscos bivalves (National program of hygiene and sanitary control of shellfish). Interministerial Normative Instruction No. 07, May 8th, 2012, Brasília: Ministry of Fisheries and Aquaculture; Ministry of Agriculture, Livestock and Food Supply.

BraziL (2012b): Statistical bulletin of fisheries and aquaculture: Brazil 2010. Brasília: Ministery of Fisheries and Aquaculture.

CAC (1999): Guidelines for the sensory evaluation of fish and shellfish in laboratories. CAC/GL 31-1999, Codex Alimentarius Commission Committee on Fish and Fishery Products, Roma: FAO WHO Food Standards Programme.

CAC (2008): Standard for live and raw bivalve molluscs. Codex Standard 292-2008, Codex Alimentarius Commission Committee on Fish and Fishery Products, Roma: FAO WHO Food Standards Programme.

Chaves, P., Pichler, H. \& Robert, M. (2002): Biological, technical and socioeconomic aspects of the fishing activity in a Brazilian estuary. J. Fish Biol., 61, 52-59.

Chigbu, P., Gordon, S. \& Strange, T. (2004): Influence of inter-annual variations in climatic factors on fecal coliform levels in Mississippi Sound. Water Res., 38, 4341-4352.

Ciminiello, P. \& Fattorusso, E. (2006): Bivalve molluscs as vectors of marine biotoxins involved in seafood poisoning. -in: Cimino, G. \& Gavagnin, M. (Eds) Molluscs. Progress in molecular and subcellular biology. 43. Springer Berlin Heidelberg; pp. 53-82.

Dufour, P. (1977): Escherichia coli: the faecal coliform. -in: Hoadley, A. \& DutKa, B.J. (Eds) Bacterial indicators: Health hazards associated with water. American Society for Testing and Materials; Conshohocken, pp. 48-58.

Dunphy, B.J., Hall, J.A., Jeffs, A.G. \& Wells, R.M.G. (2006): Selective particle feeding by the Chilean oyster, Ostrea chilensis: implications for nursery culture and broodstock conditioning. Aquacult., 261, 594-602.

EDITEL (2013): Telephonic directory for Paraná State. Curitiba: Editel Listas Telefônicas S/A.

FAO (2012): The state of world fisheries and aquaculture - 2012. Roma: Food and Agriculture Organization of the United Nations. pp. 22-46.

Fernandez-Piquer, J., Bowman, J.P., Ross, T. \& Tamplin, M.L. (2012): Molecular analysis of the bacterial communities in the live Pacific oyster (Crassostrea gigas) and the influence of postharvest temperature on its structure. J. Appl. Microbiol., 112, 1134-1143.

Heinitz, M.L., Ruble, R.D., Wagner, D.E. \& Tatini, S.R. (2000): Incidence of Salmonella in fish and seafood. J. Food Protect., 63, 579-592.

IBGE (2012): Atlas of the 2010 demographic census. Rio de Janeiro: Instituto Brazileiro de Geografia e Estatística (Brazilian Institute of Geography and Statistics).

Kohler, C.D. \& Dobrindt, U. (2011): What defines extraintestinal pathogenic Escherichia coli? Int. J. Med. Microbiol., 301, 642-647.

Kottwitz, L.B.M., Oliveira, T.C.R.M.D., Alcocer, I., Farah, S., Abrahão, W.M. \& Rodrigues, D.D.P. (2010): Epidemiological data of salmonellosis outbreaks occured between 1999 and 2008 in Parana State, Brazil. Acta Sci. Health Sci., 32, 9-15.

LAiRD, M. (1961): Microecological factors in oyster epizootics. Can. J. Zool., 39, 449-485.

Montanhini Neto, R., Zeni, T.O., Ludwig, S., Horodesky, A., Girotto, M.V.F., Castilho-Westphal, G.G. \& Ostrensky, A. (2013): Influence of environmental variables on the growth and reproductive cycle of Crassostrea (Mollusca, Bivalvia) in Guaratuba Bay, Brazil. Inver. Rep. Dev., 57, 208-218.

Pereira, M.A., Nunes, M.M., Nuernberg, L., Schulz, D. \& Batista, C.R.V. (2006): Microbiological quality of oysters (Crassostrea gigas) produced and commercialized in the coastal region of Florianópolis - Brazil. Braz. J. Microbiol., 37, 159-163.

Potasman, I., Paz, A. \& Odeh, M. (2002): Infectious outbreaks associated with bivalve shellfish consumption: a worldwide perspective. Clin. Infect. Dis., 35, 921-928.

RoBerTson, L.J. (2007): The potential for marine bivalve shellfish to act as transmission vehicles for outbreaks of protozoan infections in humans: a review. Int. J. Food Microbiol., 120, 201-216.

Silva, A.I.M., Vieira, R.H.S.F., Menezes, F.G.R., Fonteles-Filho, A.A., Torres, R.C.O. \& Sant’Anna, E.S. (2004): Bacteria of fecal origin in mangrove oysters (Crassostrea rhizophorae) in the Cocó River estuary, Ceará State, Brazil. Braz. J. Microbiol., 35, 126-130.

Silva, N., Junqueira, V.C.A., Silveira, N.F.A., Taniwaki, M.H., Santos, R.F.S. \& Gomes, R.A.R. (2010): Manual de métodos de análise microbiológica de alimentos e água (Manual of methods for microbiological analysis of food and water). São Paulo: Editora Varela, 632 pages.

Acta Alimentaria 44, 2015 